\title{
Effects and mechanism of platelet-rich plasma on military drill injury: a review
}

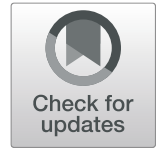

\author{
Peng-Cheng Xu, Min Xuan and Biao Cheng ${ }^{*}$
}

\begin{abstract}
Military drill injury is a significant part of military medical research. The increase of training intensity and changes in training methods lead to differences in injury types. The ideal therapeutic modality should allow rapid healing at a reasonable cost and minimize impact on patients' life. Platelet -rich plasma (PRP), a platelet concentrate, is rich in a variety of growth factors and widely used clinically as a minimally invasive treatment. It plays an important role in injury repair and rehabilitation. In this article, we review the therapeutic role of PRP in military drill injury and its possible underlying mechanisms, with a focus on plantar fasciitis, stress fractures and other common injuries, in order to provide basic support for military reserve.
\end{abstract}

Keywords: Military drill injury, Platelet- rich plasma (PRP), Plantar fasciitis, Stress fracture, Rehabilitation

\section{Background}

Nowadays, military drill has become the main task of military work in the peace era. Strengthening actual combat military drill and improving the quality and level of troop training and preparation have become a new situation for army development, aiming at maintaining and improving troop combat readiness and effectiveness $[1,2]$.

With continuous intensification of military drill, the incidence of fatigue injuries, bone and joint injuries, ligament and other soft tissue injuries have gradually increased, leading to an increase in soldier disability rate and a decrease in attendance rate, which is very detrimental to the improvement of military force. It is considered that military drill injury has become a major threat to military reserve force [3]. Consequently, it is very necessary to find safer, more effective, and minimally invasive rehabilitation treatments to improve soldiers' physical fitness and combat effectiveness.

Platelet -rich plasma (PRP) is a platelet concentrate, consisting of a large number of growth factors and

\footnotetext{
* Correspondence: chengbiaocheng@163.com

Department of Burn and Plastic Surgery, General Hospital of Southern Theater Command of Chinese PLA, No. 111 Liuhua Road, Yuexiu District, Guangzhou 510010, Guangdong Province, China
}

effective components [4], which can improve local microenvironment and promote tissue regeneration and repair $[5,6]$. Recently, PRP has been widely used in clinical practice such as orthopedics [7], dermatology [8] and plastic surgery [9]. As a minimally invasive treatment, it has achieved good results in promoting wound healing, relieving the pain of osteoarthritis and providing some functional benefits. Basic and clinical studies have found that PRP has a good application prospect in the treatment of injuries. Therefore, in this article, we will review the possible role of PRP in the treatment of military drill injury.

\section{Characteristics and application of PRP}

In 1954, Kingsley CS proposed the concept of PRP in Nature, and subsequently, the function of plateletderived growth factors and their clinical value were confirmed. PRP is a platelet concentrate extracted from autogenous blood by centrifugation and is categorized as a minimally manipulated tissue by the USA Food and Drug Administration (FDA) [10]. The platelet content in PRP is 3 to 8 times that of normal blood, and PRP also contains a small amount of other effective components such as white blood cells and fibrins [11]. When activated, platelets can release a large number of active factors

(c) The Author(s). 2020 Open Access This article is licensed under a Creative Commons Attribution 4.0 International License which permits use, sharing, adaptation, distribution and reproduction in any medium or format, as long as you give appropriate credit to the original author(s) and the source, provide a link to the Creative Commons licence, and indicate if changes were made. The images or other third party material in this article are included in the article's Creative Commons licence, unless indicated otherwise in a credit line to the material. If material is not included in the article's Creative Commons licence and your intended use is not permitted by statutory regulation or exceeds the permitted use, you will need to obtain permission directly from the copyright holder. To view a copy of this licence, visit http://creativecommons.org/licenses/by/4.0/ The Creative Commons Public Domain Dedication waiver (http://creativecommons.org/publicdomain/zero/1.0/) applies to the data made available in this article, unless otherwise stated in a credit line to the data. 
associated with tissue regeneration [12]. It is confirmed that the proportion of growth factors in PRP is similar to that of the normal body. The synergistic effect of multiple growth factors plays an important role in tissue repair, participating in matrix formation, osteogenesis, and collagen synthesis (Table 1).

PRP has many advantages (Fig. 1), so it is widely used in treatment. Investigators found that the local application of mesenchymal stem cells associated with PRP in diabetic chronic ulcers is a well-tolerated therapy and could reduce ulcer size [30]. Multiple injections of PRP could improve joint function, reduce local pain and synovial inflammation in osteoarthritis patients [31, 32]. For rotator cuff tears, local injection of PRP could reduce rotator cuff pain and improve the function of the rotator cuff, which is conducive to subsequent rehabilitation treatment [33]. Meanwhile, PRP contains white blood cells, which could significantly enhance the body's ability to remove local pathogens and resist infection [34]. Platelet-rich gels could also be used as an ideal scaffold for bone defect repair and help improve the postoperative healing microenvironment [35].

PRP has demonstrated good efficacy in a variety of conditions in orthopedics, sports medicine, oral and maxillofacial surgery, burn and plastic surgery and other fields; especially as a minimally invasive approach, it could become a promising new treatment for injury, including military drill injury (Table 2).

\section{Effects of PRP on military drill injury}

Military drill injury is a general term for a class of traumatic diseases with pathophysiological changes in military drill. According to the Diagnostic Criteria and Principles of Prevention and Treatment of Military Drill
Injury [57] and Notice on Carrying out the Monitoring and Reporting of Military Drill Injury, military drill injury can be divided into five categories (Table 3). Among these, soft tissue and bone and joint injuries are the most common of all injuries. Therefore, based on the biological characteristics of PRP, we describe in detail the possible effects of PRP on these injuries, mainly introducing its effects on stress fractures, plantar fasciitis and rehabilitation treatment.

\section{PRP and stress fractures}

Stress fracture, also known as fatigue fracture, is a bone injury caused by excessive stress under the yield strength threshold. It is a common injury in military drill, athlete training, and special work, and most often occurs in the tibia, metatarsal, and femur [58]. Increasing intensity and difficulty of military drill drive a rising incidence of stress fractures.

The symptoms of stress fractures are occult, and the rate of missed diagnosis is high after fracture. Stress fracture readily recurs under external force, resulting in delayed healing, non-healing, and even osteonecrosis $[58,59]$. Therefore, early diagnosis and recovery of bone function are critical to prognosis.

At present, for the treatments of stress fractures, brace, physical therapy, and local application of traditional Chinese medicine, which is good for blood circulation, are used [60]. However, as these treatments cannot penetrate the injury site, the therapeutic effect is often unstable. Compared with traditional therapy, minimally invasive treatment with no additional injury caused by surgery has attracted more attention.

Multiple studies in vivo and in vitro have proved that PRP can promote bone healing by the effects of multiple

Table 1 The role of growth factors contained in PRP in tissue repair

\begin{tabular}{|c|c|c|c|}
\hline Growth factors & Receptor & Role in tissue repair & References \\
\hline $\mathrm{HGF}$ & c-Met & $\begin{array}{l}\text { Stimulation of multiple cell growth, such as Hepatocytes, endothelial } \\
\text { cells, epithelial cells }\end{array}$ & [13-16] \\
\hline VEGF & $\begin{array}{l}\text { VEGFR1(FIt1), } \\
\text { VEGFR2(KDR/FIk1) } \\
\text { VEGFR3(Flk4) }\end{array}$ & $\begin{array}{l}\text { Stimulation of vascular endothelial cell proliferation and migration, } \\
\text { initiation of angiogenesis response }\end{array}$ & {$[17]$} \\
\hline TGF- $\beta$ & $\begin{array}{l}\text { TGF- } \beta \text { receptor I } \\
\text { TGF- } \beta \text { receptor II }\end{array}$ & $\begin{array}{l}\text { Involvement of inflammatory response, promotio of extracellular matrix } \\
\text { secretion, stimulation of bone matrix deposition, inhibition of osteoclast } \\
\text { formation and bone absorption }\end{array}$ & {$[18,19]$} \\
\hline IGF & IGF-IR, IGF-IIR & $\begin{array}{l}\text { Chemotaxis of fibroblasts, promotion of cartilage and bone matrix } \\
\text { formation, stimulation of ESCs proliferation and differentiation }\end{array}$ & [20-23] \\
\hline EGF & EGFR (ERBB1) & Promotion of re-epithelization and participating in angiogenesis & {$[23,24]$} \\
\hline FGFs & FGFR1, FGFR2, FGFR3 & $\begin{array}{l}\text { Mitotic stimulation of articular chondrocytes, promotion of wound } \\
\text { healing }\end{array}$ & {$[25,26]$} \\
\hline PDGF & $\begin{array}{l}\text { PDGFRa, PDGFR } \beta \\
(a \alpha, a \beta, \beta \beta)\end{array}$ & $\begin{array}{l}\text { Promotion of angiogenesis and activation of macrophages, Stimulation } \\
\text { of fibroblasts, vascular smooth muscle cells and Schwann cells } \\
\text { proliferation and activity }\end{array}$ & [27-29] \\
\hline
\end{tabular}

HGF Hepatocyte growth factor, VEGF Vascular endothelial growth factor, TGF- $\beta$ Transforming growth factor- $\beta$, IGF Insulin-like growth factor, EGF Epidermal growth factor, FGF Fibroblast growth factor, PDGF Platelet-derived growth factor 


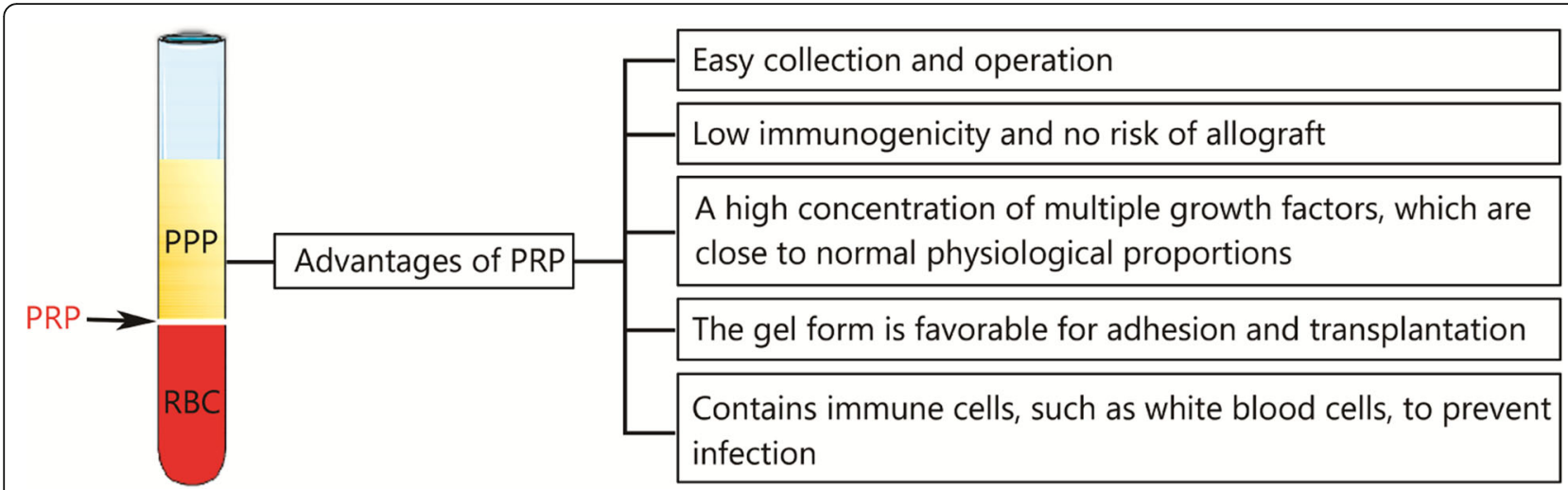

Fig. 1 The advantages of PRP. PRP. Platelet-rich plasma; PPP. Platelet-poor plasma; RBC. Red blood cells

growth factors, with satisfactory clinical efficacy. The use of PRP combined with autogenous bone graft could enhance the quantity of bone formed, and its application may be advantageous to segmental mandibular defects [61]. Another study used PRP to treat mandibular fractures and found that injecting PRP along the fracture lines could enhance bone regeneration [62]. Meanwhile, basic research of rabbit fracture injury confirmed that intra-articular injection of autologous PRP combined with autologous adipose tissue-derived stem cells can help improve repair of cartilage defects, and the effect is better than that of surgical treatment alone [63].

In addition, some studies have shown that the mechanism whereby PRP promotes bone healing may be that platelets are involved in early response to bone injury and initiate the repair response by releasing growth factors, such as platelet derived growth factor (PDGF), insulin-like growth factor (IGF) and transforming growth factor- $\beta$ (TGF- $\beta$ ) $[64,65]$. The healing process of stress fractures also involves the above growth factors, which provides a theoretical basis for the application of PRP in stress fractures.
Although there is insufficient data on specific mechanisms and efficacy of PRP injection in the treatment of refractory fractures, its application prospect and value in promoting fracture healing, and bone defect reconstruction can be foreseen. The authors believe that PRP can be used as a conventional treatment for military drillassociated stress fractures.

\section{PRP and plantar fasciitis}

Plantar fasciitis is a chronic degenerative change caused by prolonged standing or walking and overuse of the plantar aponeurosis and characterized by persistent tenderness in the lower part of the calcaneus tuberosity [66]. The characteristics of long and intensive military drill determine the prevalence of plantar fasciitis among soldiers.

Plantar fasciitis, due to degenerative changes, may become chronic, recurrent, and refractory. The ultimate goal of treatment is to relieve pain, restore fascia flexibility, and maintain foot motor function. Mild cases are mainly treated conservatively including foot orthoses, as well as foot traction training, with an effective rate up to

Table 2 The applications of PRP

\begin{tabular}{lll}
\hline Type of injuries & Functional effects & References \\
\hline Bone and cartilage damage & $\begin{array}{l}\text { Combination of bone graft to promote bone regeneration, Promotion of the } \\
\text { differentiation of transplanted cells into chondrocytes } \\
\text { Sports injuries }\end{array}$ & $\begin{array}{l}\text { Improvement of tendon healing quality and joint mobility, promotion of } \\
\text { ligament injury repair, shortening recovery time of muscle strain, rehabilitation } \\
\text { treatment of chronic sports injury }\end{array}$ \\
Acute and chronic wounds & Promotion of angiogenesis granulation tissue formation, and re-epithelialization \\
Burn wound & Promotion of burn wound repair \\
Oral and maxillofacial injuries & $\begin{array}{l}\text { Promotion of Alveolar bone regeneration, periodontal bone defect repair, and } \\
\text { maxillary sinus filling }\end{array}$ \\
Fat transplantation & Improvement of transplanted adipose tissue quality and promotion of \\
transplant survival & Promotion of facial nerve, corneal injury repair, facial rejuvenation and hair \\
Others & regeneration, etc \\
\hline
\end{tabular}


Table 3 The categories of military drill injuries

\begin{tabular}{ll}
\hline Category & Contents \\
\hline Soft tissue injury & Injuries of muscles, ligaments, tendons, fascia, synovium, etc. \\
Bone and joint injuries & Acute fracture, stress fracture, joint dislocation, joint swelling, etc. \\
Organ injuries & Functional and structural damage of corresponding organs \\
Special environmental injuries & Heatstroke, frostbite, acute altitude sickness, etc. \\
Others & Chemical poisoning, burns, bites, and stings, etc. \\
\hline
\end{tabular}

90\% [67]. However, conservative treatment requires a long period of absolute bed rest, which often affects the normal life and work of soldiers. Consequently, the concept of minimally invasive treatment is put forward and widely adopted due to its convenience and accurate effect [68].

The most commonly used method of minimally invasive treatment is corticosteroid injection. The effect of hormone therapy is immediate, and improvement is good during follow up. However, hormone therapy may increase the risk of plantar fascia rupture, fat pad necrosis, skin atrophy, and infection, and is used on a short term basis, which limits its clinical application [69]. As a result, many investigators have applied PRP for minimally invasive treatment of plantar fasciitis. In a study of 25 patients with chronic plantar fasciitis, a single injection of $5 \mathrm{ml}$ PRP using a 22 needle reduced pain but did not impair the biomechanical function of the foot, and patients resumed normal recreational activities 4 weeks after treatment, suggesting that this regeneration procedure is safe and effective [70].

Moreover, many studies have compared the effects of PRP with hormone therapy. Compared with steroid injection, local injection of PRP is an effective treatment for chronic plantar fasciitis. A prospective double-blind randomized study of PRP versus steroids showed that local injection of PRP was an effective treatment option for chronic plantar fasciitis with a long-term beneficial effect [71]. Another study compared the efficacy of PRP and corticosteroids in 60 patients with plantar fasciitis. The patients were followed up for up to 6 months, and the final evaluation showed that PRP could alleviate pain and improve the functional status, the same as hormone therapy. But unlike steroids, PRP is significantly more effective than steroids at 12 months, indicating that PRP treatment is more durable than cortisone injection. Investigators believe that PRP has good clinical effects and can avoid side effects associated with corticosteroid treatment [72]. In addition, the investigators also compared the effects of PRP and platelet-poor plasma (PPP) in chronic plantar fasciitis and found that a single injection of PRP was as effective as PPP. At the 6-month follow-up, both treatments led to significant improvement. This study has further improved the application of plasma components in plantar fasciitis. The treatment of chronic plantar fasciitis cannot only be treated with PRP but also can achieve a good prognosis combined with PPP [73]. This is very beneficial for patients because of the reduced whole blood volume by replacing PRP with PPP.

Based on clinical observation and efficacy evaluation, it is considered that PRP may replace conventional therapy as a first-line treatment for plantar fasciitis. The growth factors and effector molecules can avoid side effects caused by hormones and gradually improve chronic degenerative changes. The authors believe that it is feasible to use PRP as a potential minimally invasive treatment for military drill-associated plantar fasciitis.

\section{PRP and rehabilitation training}

Regardless of treatment of stress fractures or plantar fasciitis, the ultimate goal of injury repair is to restore function. Rehabilitation therapy is divided into sports therapy and physical therapy, which can achieve the purpose of functional recovery by regulating physiological mechanisms such as human nerves, body fluids, endocrine and immunity. It is generally believed that receiving standardized and systematic rehabilitation treatment can greatly improve the psychological and physiological health of patients [74, 75].

Military drill injuries, especially tendon injuries, are mostly chronic and overworked injuries, involving muscles, tendons, and joints. It is considered that standardized rehabilitation training can effectively reduce the functional degradation of chronic injuries and prevent recurrence, which is essential for the recovery of organ function after military drill injury. Therefore, continuous innovation of rehabilitation treatment is beneficial to the maintenance of military power.

In recent years, investigators have tried to combine PRP with rehabilitation therapy to achieve complementary effects and preliminary confirmation of the role of PRP in rehabilitation. The study by West China Hospital showed that PRP combined with conventional physical therapy could reduce shoulder pain and improve shoulder joint function, which was better than conventional physical therapy alone [76]. Another study showed that PRP injection could improve healing rates and functional outcomes in patients with rotator cuff tears [77]. These studies have confirmed that conventional physical therapy 
combined with PRP injection could effectively enhance the curative effects of traditional rehabilitation therapy.

These positive effects are thought to be associated with the release of various signalling molecules following platelet activation, as well as the inhibitory effect of PRP on pain-causing inflammatory molecules. These studies affirmed the value of PRP in rehabilitation treatment and laid a foundation for the application of PRP in the post-rehabilitation treatment of military drill injury.

\section{Application prospect of PRP in war trauma}

Although world wars have become history, regional wars are not rare. Compared with military drill injury, war traumas, such as ordinary firearm injuries, blast injuries, fuel-air bomb injuries and high-tech weapons injuries, are more serious and have a poor prognosis.

Nevertheless, the essence of care of war trauma is still tissue repair and regeneration. Currently, it is not possible to apply PRP to war trauma, but the feasibility of PRP treatment of military drill injury in this review provides a possibility for the application of PRP in war trauma in the future. With the development of technology, PRP can be prepared in new formulations, such as PRP freeze-dried powder [64] and PRP wafer [78], or other formulations in the future, like PRP-loaded sterile dressing. Improvement of PRP formulation will render transport and long-term storage more convenient, and it is hopeful that PRP can be used as a trauma dressing in battlefield first aid. Although PRP treatment cannot solve critical injuries; as an auxiliary material or minimally invasive approach, it will play an important role in frontline first aid.

\section{Deficiencies and controversies in PRP application}

In this review, we mentioned the clinical application value of PRP, including fracture treatment and rehabilitation, and propose that it be used as a potential auxiliary therapy for military training injuries. However, there is still debate about the advantages of using PRP.

\section{The necessity of randomized controlled trials (RCT) in PRP studies}

In the past decade, there has been a significant increase in the use of PRP to promote bone regeneration and soft tissue maturation. However, the additional benefits of this new technology are controversial in the literature. Although we have previously mentioned that some studies have been reported on the role of PRP in promoting bone formation and maturation rate, others have not observed any improvement.

Some studies suggested that PRP has no obvious advantage in promoting regeneration on bone defect. A study of intrabony defects found that PRP alone and bone graft both enhanced periodontal regeneration; however, the results with bone graft were better than PRP [79]. Another study assessed the effects of leukocyte-platelet-rich fibrin (L-PRF) in different intraoral bone implantation procedures, and considered its therapeutic effect was controversial, which needs further research and standardized protocols for the preparation [80]. Therefore, high quality RCT is very necessary.

There is still no consensus standard for quality control of PRP At present, the preparation methods of PRP are diversified, resulting in differences in platelet concentration and growth factor release, as well as unstable clinical effects, which is not conducive to widespread clinical application.

Here, it is considered that more high-quality RCT with large sample sizes will be needed to confirm the potential efficacy of PRP. At the same time, it is important to emphasize the importance of quality control standards, including preparation methods and dosages, which are critical and necessary for the clinical application of PRP, as well as the treatment of military drill injury.

\section{Conclusion}

In summary, although there are still many controversies, some clinical trials have also confirmed the application value of PRP in promoting repair, relieving pain and providing some functional benefits, such as osteoarthritis [81, 82], synovitis [83], and refractory wounds [84, 85]. In the future, PRP may be a potential auxiliary therapy for military drill injury.

\section{Abbreviations}

PRP: Platelet -rich plasma; PPP: Platelet-poor plasma; MSCs: Mesenchymal stem cells; HGF: Hepatocyte growth factor; VEGF: Vascular endothelial growth factor; TGF- $\beta$ : Transforming growth factor- $\beta$; IGF: Insulin-like growth factor; EGF: Epidermal growth factor; FGF: Fibroblast growth factor; PDGF: Plateletderived growth factor

\section{Acknowledgements}

Not applicable.

Authors' contributions

PCX was a major contributor in writing the manuscript. PCX and MX collected and analyzed the literature. BC participated in critically revising the article. All authors read and approved the final manuscript.

\section{Funding}

This work was supported by the National Natural Science Foundation of China (81671924 and 81272105), the Science and Technology Key Project of Guangdong Province (2014B020212010), the National Key Research and Development Plan of China (2017YFC1103301), and Military Medical Innovation Special Projects (18CXZ029).

Availability of data and materials

All data generated or analysed during this study are included in this published article.

Ethics approval and consent to participate Not applicable.

Consent for publication

Not applicable.

Competing interests

The authors declare that they have no competing interests. 
Received: 10 March 2020 Accepted: 4 November 2020

Published online: 22 November 2020

\section{References}

1. Gao X, Ding J. The internal structure, main characteristics and great significance of xi Jinping's thought of strengthening the army (in Chinese). Study Pract. 2018;35(1):18-25

2. Zhang Q. Thoroughly implement Xi Jinping's thought of strengthening the army and strive to create a new situation in the cause of national defense mobilization (in Chinese). Natl Def. 2019:8:5-7.

3. Dijksma I, Zimmermann WO, Hertenberg EJ, Lucas C, Stuiver MM. One out of four recruits drops out from elite military training due to musculoskeletal injuries in the netherlands armed forces. BMJ Mil Health. 2020; bmjmilitary2020-001420. https://doi.org/10.1136/bmjmilitary-2020-001420.

4. Boswell SG, Cole BJ, Sundman EA, Karas V, Fortier LA. Platelet-rich plasma: a milieu of bioactive factors. Arthroscopy. 2012;28(3):429-39.

5. Acebes-Huerta A, Arias-Fernandez T, Bernardo A, Munoz-Turrillas MC Fernandez-Fuertes J, Seghatchian J, et al. Platelet-derived bio-products: classification update, applications, concerns and new perspectives. Transfus Apher Sci. 2020:59(1):102716

6. Alsousou J, Ali A, Willett $K$, Harrison P. The role of PRP in tissue regeneration. Platelets. 2013;24(3):173-82.

7. Sheth U, Simunovic N, Klein G, Fu F, Einhorn TA, Schemitsch E, et al. Efficacy of autologous platelet-rich plasma use for orthopaedic indications: a metaanalysis. J Bone Joint Surg Am. 2012;94(4):298-307.

8. Hesseler MJ, Shyam N. Platelet-rich plasma and its utility in medical dermatology: a systematic review. J Am Acad Dermatol. 2019;81(3):834-46.

9. Hesseler MJ, Shyam N. Platelet-rich plasma and its utility in the treatment of acne scars: a systematic review. J Am Acad Dermatol. 2019;80(6):1730-45.

10. Chahla J, Cinque ME, Piuzzi NS, Mannava S, Geeslin AG, Murray IR, et al. A call for standardization in platelet-rich plasma preparation protocols and composition reporting: a systematic review of the clinical orthopaedic literature. J Bone Joint Surg Am. 2017:99(20):1769-79.

11. Lana JF, Macedo A, Ingrao I, Huber SC, Santos GS, Santana M. Leukocyterich PRP for knee osteoarthritis: current concepts. J Clin Orthop Trauma. 2019;10(Suppl 1):S179-82.

12. Anitua $\mathrm{E}$, Alkhraisat MH, Orive G. Perspectives and challenges in regenerative medicine using plasma rich in growth factors. J Control Release. 2012;157(1):29-38.

13. Yu Z, Zeng J, Wang J, Cui Y, Song X, Zhang Y, et al. Hepatocyte growth factor-regulated tyrosine kinase substrate is essential for endothelial cel polarity and cerebrovascular stability. Cardiovasc Res. 2020. https://doi.org/ 10.1093/cvr/cvaa016

14. Almale L, Garcia-Alvaro M, Martinez-Palacian A, Garcia-Bravo M, Lazcanoiturburu N, Addante A, et al. C-met signaling is essential for mouse adult liver progenitor cells expansion after transforming growth factor-betainduced epithelial-mesenchymal transition and regulates cell phenotypic switch. Stem Cells. 2019:37(8):1108-18.

15. Chmielowiec J, Borowiak M, Morkel M, Stradal T, Munz B, Werner S, et al. C-met is essential for wound healing in the skin. J Cell Biol. 2007; 177(1):151-62

16. Peura M, Bizik J, Salmenpera P, Noro A, Korhonen M, Patila T, et al. Bone marrow mesenchymal stem cells undergo nemosis and induce keratinocyte wound healing utilizing the HGF/c-met/PI3K pathway. Wound Repair Regen. 2009:17(4):569-77.

17. Simons M, Gordon E, Claesson-Welsh L. Mechanisms and regulation of endothelial VEGF receptor signaling. Nat Rev Mol Cell Biol. 2016;17(10):611-25.

18. Duan $X$, Liu J, Zheng $X$, Wang Z, Zhang $Y$, Hao $Y$, et al. Deficiency of ATP6V1H causes bone loss by inhibiting bone resorption and bone formation through the TGF-beta1 pathway. Theranostics. 2016;6(12): 2183-95.

19. Weivoda MM, Ruan M, Pederson L, Hachfeld C, Davey RA, Zajac JD, et al. Osteoclast TGF-beta receptor signaling induces Wnt1 secretion and couples bone resorption to bone formation. J Bone Miner Res. 2016;31(1):76-85.

20. Kofidis T, de Bruin JL, Yamane T, Balsam LB, Lebl DR, Swijnenburg RJ, et al. Insulin-like growth factor promotes engraftment, differentiation, and functional improvement after transfer of embryonic stem cells for myocardial restoration. Stem Cells. 2004;22(7):1239-45.

21. Nakasaki M, Yoshioka K, Miyamoto Y, Sasaki T, Yoshikawa H, Itoh K. IGF-I secreted by osteoblasts acts as a potent chemotactic factor for osteoblasts. Bone. 2008:43(5):869-79.
22. Palka JA, Karna E, Miltyk W. Fibroblast chemotaxis and prolidase activity modulation by insulin-like growth factor II and mannose 6-phosphate. Mol Cell Biochem. 1997;168(1-2):177-83.

23. Haase I, Evans R, Pofahl R, Watt FM. Regulation of keratinocyte shape, migration and wound epithelialization by IGF-1- and EGF-dependent signalling pathways. J Cell Sci. 2003;116(Pt 15):3227-38.

24. Rao L, Giannico D, Leone P, Solimando AG, Maiorano E, Caporusso C, et al. HBEGF-EGFR signaling in bone marrow endothelial cells mediates angiogenesis associated with multiple myeloma. Cancers (Basel). 2020;12(1):173.

25. Xie J, Bian H, Qi S, Xu Y, Tang J, Li T, et al. Effects of basic fibroblast growth factor on the expression of extracellular matrix and matrix metalloproteinase-1 in wound healing. Clin Exp Dermatol. 2008;33(2):176-82.

26. Chen TM, Chen YH, Sun HS, Tsai SJ. Fibroblast growth factors: potential novel targets for regenerative therapy of osteoarthritis. Chin J Physiol. 2019; 62(1):2-10.

27. Verma R, Negi G, Kandwal A, Chandra H, Gaur DS, Harsh M. Effect of autologous PRP on wound healing in dental regenerative surgeries and its correlation with PDGF levels. Asian J Transfus Sci. 2019;13(1):47-53.

28. Sowa Y, Kishida T, Tomita K, Adachi T, Numajiri T, Mazda O. Involvement of PDGF-BB and IGF-1 in activation of human schwann cells by platelet-rich plasma. Plast Reconstr Surg. 2019;144(6):1025e-36e.

29. Oya T, Zhao YL, Takagawa K, Kawaguchi M, Shirakawa K, Yamauchi T, et al. Platelet-derived growth factor-b expression induced after rat peripheral nerve injuries. Glia. 2002;38(4):303-12

30. Stessuk T, Ribeiro-Paes JT, Colpas PT, Martins AP, Rehder J, Bosnardo C, et al. A topical cell therapy approach for diabetic chronic ulcers: effects of mesenchymal stromal cells associated with platelet-rich plasma. J Cosmet Dermatol. 2020;19(10):2669-78.

31. Garbin LC, Olver CS. Platelet-rich products and their application to osteoarthritis. J Equine Vet Sci. 2020;86:102820.

32. Chouhan DK, Dhillon MS, Patel S, Bansal T, Bhatia A, Kanwat H. Multiple platelet-rich plasma injections versus single platelet-rich plasma injection in early osteoarthritis of the knee: an experimental study in a Guinea pig model of early knee osteoarthritis. Am J Sports Med. 2019:47(10):2300-7.

33. Chen X, Jones IA, Togashi R, Park C, Vangsness CJ. Use of platelet-rich plasma for the improvement of pain and function in rotator cuff tears: a systematic review and meta analysis with bias assessment. Am J Sports Med. 2019:488(8):036354651988142.

34. Li H, Hamza T, Tidwell JE, Clovis N, Li B. Unique antimicrobial effects of PRP and its efficacy as a prophylaxis to prevent implant-associated spinal infection. AdvV Healthc Mater. 2013;2(9):1277-84.

35. Scala M, Gipponi M, Mereu P, Strada P, Corvo R, Muraglia A, et al. Regeneration of mandibular osteoradionecrosis defect with platelet-rich plasma gel. In Vivo. 2010;24(6):889-93

36. Huang G, Hua S, Yang T, Ma J, Yu W, Chen X. Platelet-rich plasma shows beneficial effects for patients with knee osteoarthritis by suppressing inflammatory factors. Exp Ther Med. 2018;15(3):3096-102.

37. Liu J, Song W, Yuan T, Xu Z, Jia W, Zhang C. A comparison between platelet-rich plasma (PRP) and hyaluronate acid on the healing of cartilage defects. PLoS One. 2014;9(5):e97293.

38. Tong S, Zhang C, Liu J. Platelet-rich plasma exhibits beneficial effects for rheumatoid arthritis mice by suppressing inflammatory factors. Mol Med Rep. 2017:16(4):4082-8.

39. Tsai WC, Yu TY, Chang GJ, Lin LP, Lin MS, Pang JS. Platelet-rich plasma releasate promotes regeneration and decreases inflammation and apoptosis of injured skeletal muscle. Am J Sports Med. 2018;46(8):1980-6.

40. Lane JG, Healey RM, Chase DC, Amiel D. Use of PRP to enhance tendon function and cellularity. Am J Orthop (Belle Mead NJ). 2013;42(5):209-14.

41. Alsousou J, Keene DJ, Harrison P, Hulley P, Wagland S, Thompson JY, et al. PRP injection for adults with acute achilles tendon rupture: the PATH-2 RCT. NIHR Journals Library: Southampton (UK). 2019. https://doi.org/10.3310/ eme06120.

42. De Angelis B, D'Autilio M, Orlandi F, Pepe G, Garcovich S, Scioli MG, et al. Wound healing: in vitro and in vivo evaluation of a bio-functionalized scaffold based on hyaluronic acid and PRP in chronic ulcers. J Clin Med. 2019;8(9):1486

43. Bhattacharjee R, Sawatkar G, Vinay K. Platelet-rich fibrin dressings in treating nonhealing leg ulcers. J Am Acad Dermatol. 2019:80(2):e31-2.

44. Suthar M, Gupta S, Bukhari S, Ponemone V. Treatment of chronic non-healing ulcers using autologous PRP: a case series. J Biomed Sci. 2017;24(1):16 
45. Zheng W, Zhao DL, Zhao YQ, Li ZY. Effectiveness of platelet-rich plasma in burn wound healing: a systematic review and meta-analysis. J Dermatolog Treat.2020;(2):1-25

46. Fan Y, Perez K, Dym H. Clinical uses of platelet-rich fibrin in oral and maxillofacial surgery. Dent Clin N Am. 2020;64(2):291-303.

47. Chou TM, Chang HP, Wang JC. Autologous platelet concentrates in maxillofacial regenerative therapy. Kaohsiung J Med Sci. 2020;36(5):305-10.

48. Dominijanni A, Cristofaro MG, Brescia A, Giudice M. Platelet gel in oral and maxillofacial surgery: a single-Centre experience. Blood Transfus. 2012;10(2):200-4.

49. Li F, Guo W, Li K, Yu M, Tang W, Wang H, et al. Improved fat graft survival by different volume fractions of platelet-rich plasma and adipose-derived stem cells. Aesthet Surg J. 2015;35(3):319-33.

50. Xiong S, Qiu L, Su Y, Zheng H, Yi C. Platelet-rich plasma and plateletr-rich fibrin enhance the outcomes of fat grafting: a comparative study. Plast Reconstr Surg. 2019;143(6):1201e-12e.

51. Smith OJ, Jell G, Mosahebi A. The use of fat grafting and platelet-rich plasma for wound healing: a review of the current evidence. Int Wound J. 2019;16(1):275-85.

52. Cai J, Tian J, Chen K, Cheng LH, Xuan M, Cheng B. Erbium fractional laser irradiation combined with autologous platelet-rich plasma and platelet-poor plasma application for facial rejuvenation. J Cosmet Dermatol. 2019;19(8): 1975-9.

53. Zhu M, Kong D, Tian R, Pang M, Mo M, Chen $Y$, et al. Platelet sonicates activate hair follicle stem cells and mediate enhanced hair follicle regeneration. J Cell Mol Med. 2020;24(2):1786-94.

54. Panda A, Jain M, Vanathi M, Velpandian T, Khokhar S, Dada T. Topical autologous platelet-rich plasma eyedrops for acute corneal chemical injury. Cornea. 2012;31(9):989-93.

55. Li L, Cai J, Yuan Y, Mao Y, Xu L, Han Y, et al. Platelet-rich plasma can release nutrient factors to promote facial nerve crush injury recovery in rats. Saudi Med J. 2019:40(12):1209-17.

56. Stavrakas M, Karkos PD, Markou K, Grigoriadis N. Platelet-rich plasma in otolaryngology. J Laryngol Otol. 2016;130(12):1098-102.

57. Huang CL, Zhang L, Xue G. Research on the establishment and application of diagnostic criteria and prevention principles of military drill injuries and its significance (in Chinese). Med J Chin PLA. 2004;29(4):286-8.

58. Knapik JJ, Reynolds K, Hoedebecke KL. Stress fractures: etiology, epidemiology, diagnosis, treatment, and prevention. J Spec Oper Med. 2017;17(2):120-30.

59. Mallinson RJ, Southmayd EA, De Souza MJ. Geometric and "true" densitometric characteristics of bones in athletes with stress fracture and menstrual disturbances: a systematic review. Sports Med. 2019;49(7):1059-78.

60. Lin W. The clinical research of Huoxue Huayu decoction combined with extracor poreal shock wave in treating the tibia stress fractures of the soldiers (Doctoral dissertation). 2016.

61. Magesh DP, Kumaravelu C, Maheshwari GU. Efficacy of platelet-rich plasma in the reconstruction of mandibular segmental defects using iliac bone grafts. J Maxillofac Oral Surg. 2013;12(2):160-7.

62. Daif ET. Effect of autologous platelet-rich plasma on bone regeneration in mandibular fractures. Dent Traumatol. 2013;29(5):399-403.

63. Hsu Y, Sheu S, Wang C, Chuang M, Chung P, Luo Y, et al. The effect of adipose-derived mesenchymal stem cells and chondrocytes with plateletrich fibrin releasates augmentation by intra-articular injection on acute osteochondral defects in a rabbit model. Knee. 2018;25(6):1181-91.

64. Kinoshita H, Orita S, Inage K, Fujimoto K, Shiga Y, Abe K, et al. Freeze-dried platelet-rich plasma induces osteoblast proliferation via platelet-derived growth factor receptor-mediated signal transduction. Asian Spine J. 2020; 14(1):1-8.

65. Kim J, Ha Y, Kang NH. Effects of growth factors from platelet-rich fibrin on the bone regeneration. J Craniofac Surg. 2017;28(4):860-5.

66. Wearing SC, Smeathers JE, Urry SR, Hennig EM, Hills AP. The pathomechanics of plantar fasciitis. Sports Med. 2006;36(7):585-611.

67. Anderson J, Stanek J. Effect of foot orthoses as treatment for plantar fasciitis or heel pain. J Sport Rehabil. 2013;22(2):130-6.

68. Al-Boloushi Z, Lopez-Royo MP, Arian M, Gomez-Trullen EM, Herrero P. Minimally invasive non-surgical management of plantar fasciitis: a systematic review. J Bodyw Mov Ther. 2019;23(1):122-37.

69. Mohd Khalid S, Bajuri MY. Unexpected sequelae of plantar fasciitis: latrogenic calcaneal osteomyelitis following plantar heel injection. Malays Fam Physician. 2019;14(3):80-3.
70. Ragab EM, Othman AM. Platelets rich plasma for treatment of chronic plantar fasciitis. Arch Orthop Trauma Surg. 2012;132(8):1065-70.

71. Soraganvi P, Nagakiran KV, Raghavendra-Raju RP, Anilkumar D, Wooly S, Basti BD, et al. Is PRP injection more effective than steroid injection in the treatment of chronic plantar fasciitis in achieving long-term relief? Malays Orthop J. 2019;13(3):8-14.

72. Jain K, Murphy PN, Clough TM. Platelet rich plasma versus corticosteroid injection for plantar fasciitis: a comparative study. Foot (Edinb). 2015;25(4): 235-7.

73. Malahias MA, Mavrogenis AF, Nikolaou VS, Megaloikonomos PD, Kazas ST,

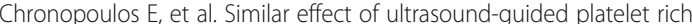
plasma versus platelet-poor plasma injections for chronic plantar fasciitis. Foot (Edinb). 2019;38:30-3.

74. Din S, Shah M, Asadullah, Jamal H, Bilal M. Rehabilitation and social adjustment of people with burns in society. Burns. 2015:41(1):106-9.

75. Anekwe DE, Biswas S, Bussieres A, Spahija J. Early rehabilitation reduces the likelihood of developing intensive care unit-acquired weakness: a systematic review and meta-analysis. Physiotherapy. 2020;107:1-10.

76. Huang M, Hu Y, Wan T, Wang J, Zeng X, Zhang C, et al. Clinical effect of ultrasound-guided anterior platelet rich plasma injection on the treatment of rotator cuff injury (in Chinese). West China Med J. 2019;34(12):1407-11.

77. Hurley ET, Lim Fat D, Moran CJ, Mullett H. The efficacy of platelet rich plasma and platelet-rich fibrin in arthroscopic rotator cuff repair: a metaanalysis of randomized controlled trials. Am J Sports Med. 2019;47(3):1-8.

78. Yassin GE, Dawoud MHS, Wasfi R, Maher A, Fayez AM. In vitro comparative lyophilized PRP wafer and powder for wound-healing enhancement: formulation, and studies. Drug Dev Ind Pharm. 2019;45(8):1379-87.

79. Jalaluddin M, Mahesh J, Mahesh R, Jayanti I, Faizuddin M, Kripal K, et al. Effectiveness of PRP and bone graft in the treatment of intrabony defects: a clinico-radiographic study. Open Dent J. 2018;12:133-54.

80. Dragonas P, Katsaros T, Avila-Ortiz G, Chambrone L, Schiavo JH, Palaiologou A. Effects of leukocyte-platelet-rich fibrin (L-PRF) in different intraoral bone grafting procedures: a systematic review. Int J Oral Maxillofac Surg. 2019; 48(2):250-62.

81. Raeissadat SA, Ghorbani E, Sanei TM, Soleimani R, Rayegani SM, Babaee M, et al. MRI changes after platelet rich plasma injection in knee osteoarthritis (randomized clinical trial). J Pain Res. 2020;13:65-73.

82. Asjid R, Faisal T, Qamar K, Khan SA, Khalil A, Zia MS. Platelet-rich plasmainduced inhibition of chondrocyte apoptosis directly affects cartilage thickness in osteoarthritis. Cureus. 2019;11(11):e6050.

83. Yin J, Xu Z, Liu J. Alleviation of synovitis caused by joint instability with application of PRP. Thromb Res. 2020;186:20-5.

84. Martinez-Zapata MJ, Marti-Carvajal AJ, Sola I, Exposito JA, Bolibar I, Rodriguez L, et al. Autologous platelet-rich plasma for treating chronic wounds. Cochrane Database Syst Rev. 2016;5(5):CD006899.

85. Ozer K, Colak O. Leucocyte- and platelet-rich fibrin as a rescue therapy for small-to-medium-sized complex wounds of the lower extremities. Burns Trauma. 2019;7:11.

Ready to submit your research? Choose BMC and benefit from:

- fast, convenient online submission

- thorough peer review by experienced researchers in your field

- rapid publication on acceptance

- support for research data, including large and complex data types

- gold Open Access which fosters wider collaboration and increased citations

- maximum visibility for your research: over $100 \mathrm{M}$ website views per year

At $\mathrm{BMC}$, research is always in progress.

Learn more biomedcentral.com/submission 